\title{
Global impact of COVID-19 on agriculture: role of sustainable agriculture and digital farming
}

\author{
Adithya Sridhar $^{1} \cdot$ Akash Balakrishnan $^{2} \cdot$ Meenu Mariam Jacob ${ }^{1} \cdot$ Mika Sillanpää $^{3} \cdot$ Nanditha Dayanandan $^{1} \mathbb{C}$
}

Received: 2 September 2021 / Accepted: 18 February 2022 / Published online: 8 March 2022

(c) The Author(s), under exclusive licence to Springer-Verlag GmbH Germany, part of Springer Nature 2022

\begin{abstract}
The rise and spread of the coronavirus pandemic (COVID-19) has created an imbalance in all sectors worldwide, massively disrupting the global economy. Social distancing, quarantine regulations, and strict travel restrictions have led to a major reduction in the workforce and loss of jobs across all industrial sectors. One of the sectors completely exposed was the agriculture and food sector. The initiation of a nationwide lockdown by the government resulted in the shutdown of industries globally impacting the overall supply chain from farmer to consumer. The need of the hour is to propose effective solutions which can serve the dual purpose of market growth as well as customer satisfaction. This paper reviews the impact of COVID19 on the agro-food system and its economy stressing critical factors like food production, demand, price hikes, security, and supply chain resilience. To conserve natural resources and meet the sustainable development goals (SDG), importance has been given to adopting sustainable agricultural practices with a prime focus on techniques like urban agriculture, crop rotation, hydroponics, and family farming. Possible advancements like the use of digital tools, mainly artificial intelligence, machine learning, deep learning, and block-chain technology, in the agro-food sector have been discussed as they could be a promising tool to develop a self-reliant society. This work would be a perfect platform to understand the growing impact of the pandemic as well as supporting cost-effective solutions for a green ecosystem.
\end{abstract}

Keywords Agriculture $\cdot$ COVID-19 $\cdot$ Food security $\cdot$ Sustainable farming $\cdot$ Digitalization

\section{Introduction}

The outbreak of the global coronavirus (COVID-19) pandemic posed a significant threat to health with a ripple effect on various sectors impacting human life. The virus rapidly

Responsible Editor: Philippe Garrigues

Adithya Sridhar and Akash Balakrishnan contributed equally to this study

\section{Nanditha Dayanandan}

1 Department of Chemical Engineering, College of Engineering and Technology, SRM Institute of Science \& Technology, Kattankulathur 603 203, Chengalpattu, Tamil Nadu, India

2 Department of Chemical Engineering, National Institute of Technology, Rourkela, Odisha 769 008, India

3 Department of Chemical Engineering, School of Mining, Metallurgy, and Chemical Engineering, University of Johannesburg, P.O. Box 17011, Doornfontein 2028, South Africa spread and affected economies thus bringing out inefficiencies in both the agriculture and industrial sector resulting in food insecurity (Jámbor et al. 2020). Different national and international organizations like Food and Agricultural Organization (FAO), International Food Policy Research Institute (IFPRI) have tried to keep the global market open (Pu and Zhong, 2020). However, the rapid transmission of the virus resulted in several nations restricting international trade and travel resulting in poverty, hunger, and malnutrition across the globe (Torero, 2020).

The virus showed its first signs in December 2019 when a pneumonia outbreak took place in the Wuhan province of China (Abbott et al. 2020; Kumar et al. 2020). World Health Organization (WHO) later declared the outbreak of COVID-19 as public health emergency of international concern in January 2020 (Saadat et al. 2020; Usman et al. 2020). The continuous transmission of the virus has led to crude mortality of $3.4 \%$ across the world. The initial outbreak of COVID-19 was seen in China and gradually spread to 190 countries across the world (Sharma et al. 2020a). As of September 2020, India has become one of the top 
epicenters of COVID-19. According to the National Institute of Epidemiology and recent Bloomberg report, the country could easily surpass USA and Brazil due to the daily surge in cases (Altstedter, 2020). The COVID-19 virus can be transmitted through direct surface contact, touch, or via respiratory drops while sneezing or coughing (Mandal et al. 2020). The virus has also been shown to impact individuals with low immunity or those who live in densely populated region (Eisenberg, 2020).

The hidden cascading domino effect has proved prevention as a challenging path in this interconnected world. The majority of the growing sectors have been adversely impacted including the agriculture and food industry. The sector continues to combat challenges from the aspect of the producer as well as consumers for restrictions, labor shortages, speed to market, and priority buying of commodities (Luckstead et al. 2020; Rajput et al. 2020).

For decades, agriculture has played a critical part in fostering the economy of different nations. It has been the source for early development in countries like the UK, France, and the Netherlands (Allen, 2000). Major transformations in the agriculture sector were observed in the late 1900s where there was a switch from labor-intensive and bullock farming to mechanization and usage of large equipment in the twenty-first century as depicted in Fig. 1 (de Janvry and Sadoulet 2020). Along with modern equipment, the improvements in crop varieties, animal-based farming, and usage of different fertilizers were other interests to increase yield and production capacity. This created a spark for revolutionizing the agro-food sector.

The agro-industry has always been the expected root of growth for balancing import-export and managing international trade relations (Qiao et al. 2019). With the sudden outbreak of COVID-19, the sector has been hit with severe issues related to trade, transport, price volatility, and rising debts. To add on, the declaration of nationwide lockdown exacerbated the situation resulting in shortage of labor supply, lack of availability of fertilizers, imbalance in supply-demand, and problems associated with post-harvesting due to social distancing (Consultancy Asia, 2020; Insights, 2020).

With the ongoing COVID-19 pandemic, the agriculture sector is facing huge challenges in satisfying the increasing demands for food. Factors like health and nutrition-based foods, improving safety, poverty reduction, and environmental sustainability have been of vital importance since the disease outbreak (Christiaensen and Martin 2018; Chatterjee, 2020). An increase in the production capacity of crops and foods giving adequate focus to safety and sustainability has become the top priority during this pandemic. The use of eco-friendly fertilizers and other biological alternatives may enhance crop productivity and replace harmful chemicals. However, these products are expensive and take months to deliver to the market. In recent years, there has been a promising approach toward sustainable agriculture and farming to deliver better health and economic outcomes (Arora and Mishra 2016; Hellin et al. 2020). Capitalizing the advantage of information and communication technologies (ICTs), functioning and efficiency of the supply chain management can be increased extensively. For instance, the mobile procurement of perishable commodities can be incentivized (Kumar et al., 2020). Digital technologies, and satellite and drone technologies can allow remote sensing for crop growth developments and soil moisture. Computing techniques can allow digital tools like artificial intelligence (AI), machine learning (ML), and deep learning to process large amounts of data in a short span of time for faster speed to market. However, the need of the hour is to increase the value of such digital technologies for a better reach and an efficient supply chain.

This review addresses the impact of the COVID-19 pandemic on the agro-food sector in the areas of food
Fig. 1 Agricultural transformation through the years

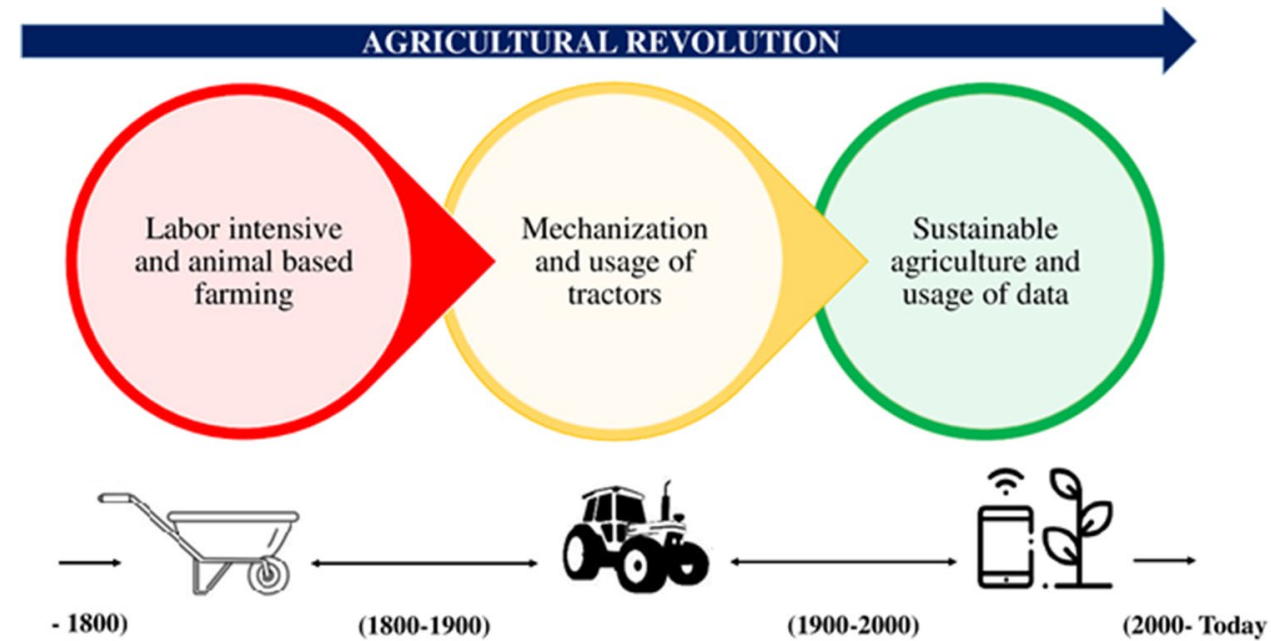


production, pricing, and supply chain. A special focus has been given to the adoption of sustainable farming techniques and agricultural practices to ensure food security. Few recommendations have been addressed for enhanced agriculture with the utilization of digital technologies like AI, AI-based concepts, and block-chain as they could progress to an agriculture creating a green agro-ecosystem.

\section{Impact of COVID-19 on agriculture}

The agriculture sector is a source of income for more than 1 billion people across the globe. Agriculture production, including different stages from planting, growing, nurturing, harvesting to shipping of goods, needs labor requirements (Workie et al. 2020). The dependence of market value chains, food, and agricultural sectors are considered to be less resilient due to the occurrence of the pandemic. The impact of COVID-19 on the agricultural sector is discussed below (Fig. 2).

\section{Agriculture production}

Agriculture production has been an engine for reducing poverty and food security. The ongoing pandemic has adversely affected the value chain from farmers to retailers (Sharma et al. 2020b). Local restrictions and travel bans have led to limited access to farm inputs (seeds, fertilizers, etc.) and resulted in low agricultural production (Aromolaran and Muyanga, 2020). This could be attributed to the hike in the price of farm inputs like seeds, chemical fertilizers, reduced household income, lack of availability of inputs, and labor shortage during the initial months of the pandemic (Aromolaran and Muyanga 2020).

The global pandemic caused a shortage of workers for the cultivation of non-staple crops like fruits and vegetables affected planting and harvesting. Canada, USA, and Europe have a shortage of nearly 1 million migrant workers from Eastern Europe and African countries (FAO 2020a). In India, the nationwide lockdown has adversely affected the harvest of winter crops. Lockdown has forced the migrant laborers as well as small-scale shopkeepers to forcefully shut down their business and return to their homes leading to a shortage of labor. A financial imbalance was also observed with the exchange of different types of equipment that the small-scale farmers rent for harvest (S. Mahendra Dev 2020). A recent report estimated that there has been an overall decrease in agriculture production in Southeast Asian countries of 3.11\% (17.03 million tons) in the first quarter of 2020 due to the absence of laborers on the farm (Gregorio and Ancog, 2020).

Developed countries utilize highly sophisticated mechanized equipment for the cultivation of crops like wheat, rice, maize, and other vegetables. These types of machinery can be used for different activities like land developments, irrigation, planting, and sowing. Due to labor-intensive farming, many staple crops had not been cultivated due to lockdown measures, leading to low food production and food insecurity (FAO 2020b). On the contrary, due to excessive production of crops and imposing of strict rules and regulations (Trade and travel), farmers were forced to dump crops in various parts of Nepal, USA, and India (Poudel and Subedi 2020; WFO 2020a, b). The shortage in the employees and poor food supply network
Fig. 2 Describing the overall impact of COVID-19 on agriculture and farming systems

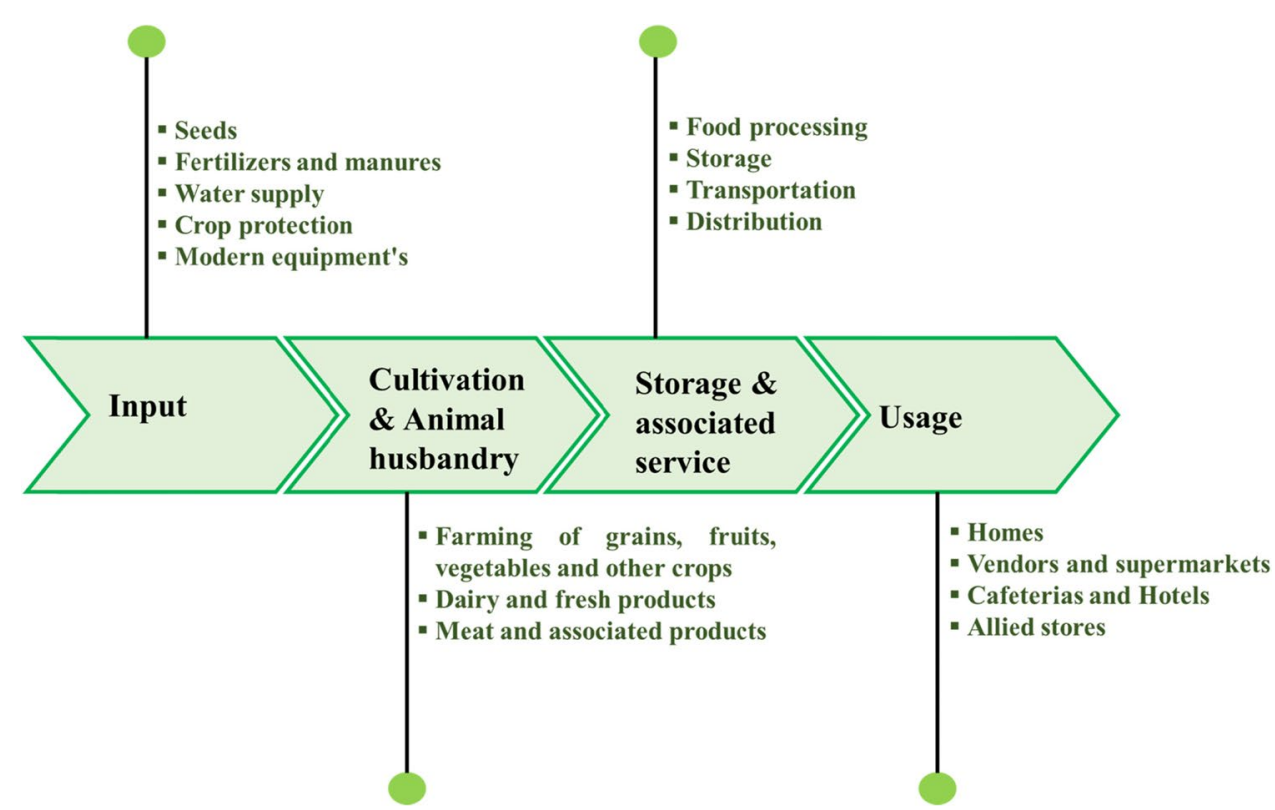


forced the industries to shut down resulting in huge uncertainties in the global food sector (FAO 2020c).

Agriculture production has also indirectly disrupted the fertilizer and pesticide industry with the imbalance in the supply of fertilizers like urea, potash, ammonia, and phosphate which are necessary for the growth and nutrient management of plants. The sudden factory shutdown and limited transportation facilities delayed the flow of product toward the market and farmers (Affognon et al. 2020). This led to many crops getting rotten and several being used as manure owing to massive losses.

Different coping strategies were adopted to strengthen the agro-food sector during the pandemic. Some of them were (1) mechanization of agriculture to reduce the load among workers and to avoid time delays (Daum and Birner 2020); (2) introducing staggered shifts of labors, which could be one of the ways adopted to ensure the minimal distance between workers, therefore minimizing the risk of transmission (Laborde et al. 2020); (3) post-harvest management to minimize the harvest loss and to ensure proper storage of goods through hermetic packaging and triple bagging technology against seed infestation for grains and grains (Baoua et al. 2014; Ng'ang' a et al. 2016; Afzal et al. 2020); and (4) implementation of farming support and extension service for the grievances of farmers on allied areas (Baloch and Thapa 2019; Affognon; et al. 2020).

\section{Food demand}

The consumption of food during the lockdown rose due to rapid transmission leading to panic shopping and back stocking of commodities. Various staple foods like beans, rice, and packaged foods were in great demand due to better shelf life. At the beginning of March, consumption of products like pasta, flour, rice, and canned foods increased by more than $150 \%$ as they had a higher shelf life (Mengoub, 2020).

As an aftereffect of COVID-19, the demand for food drastically increased. For instance, the "food away from home" sector accounts for $10 \%$ of the fruit consumption, $32 \%$ of vegetables, $25 \%$ of dairy, and $31 \%$ of cereals. This particular sector accounts for at least 25 to $30 \%$ of total sales of fresh fruit and vegetables. In addition to logistical challenges, households' consumption patterns at home are different from those away from home (OECD 2020).

\section{Food prices}

As a major effect of COVID-19, the global food price has linearly increased from February 2020. According to the FAO Food Price Index (FFPI), the international price of food commodities reached the highest level of 97.19 points in September 2020 (FAO 2020d). The value increased by 5\% since last year and was the highest between September and

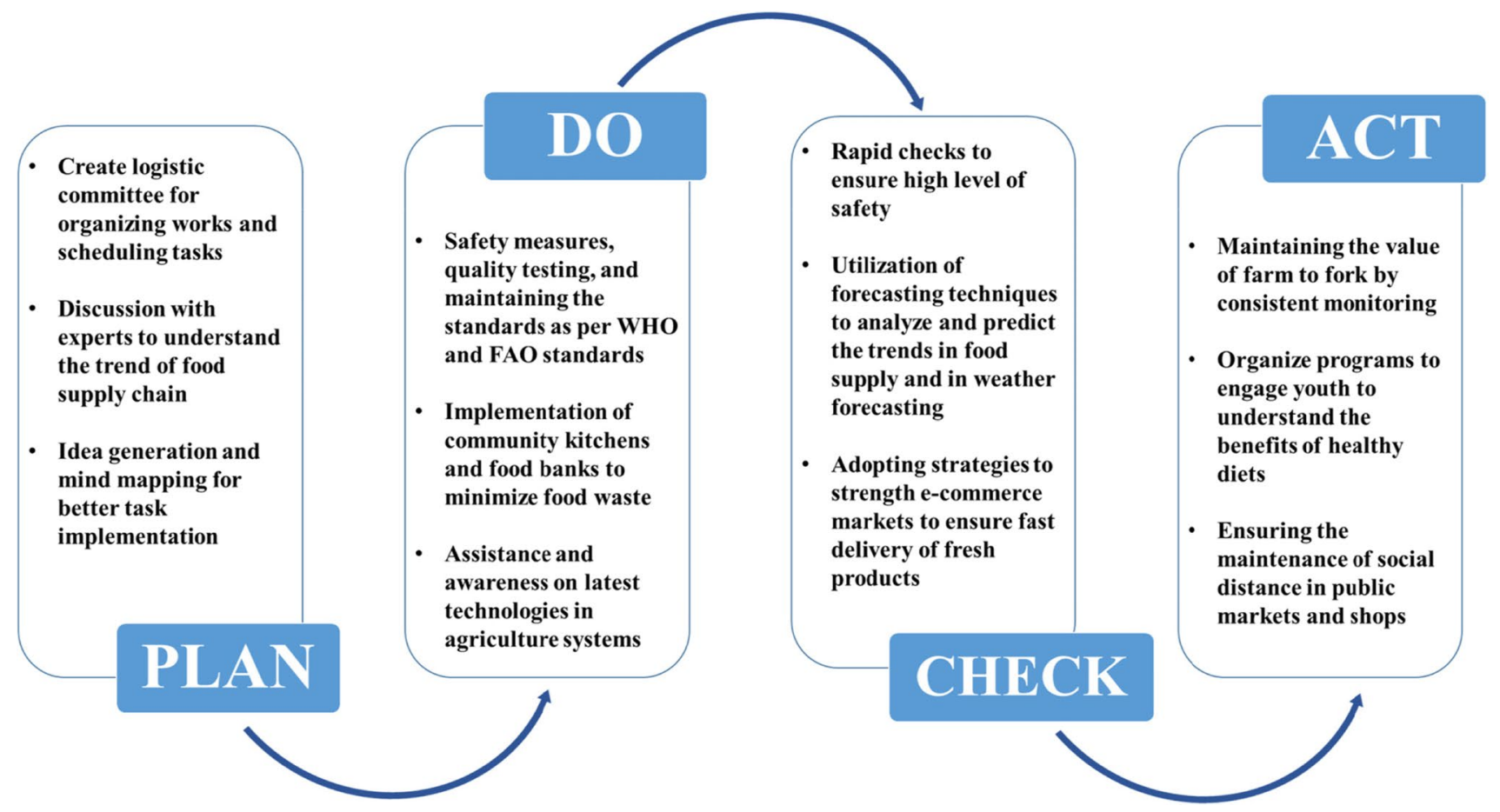

Fig. 3 Possible implementation of lean PDCA model by the government 
February (Fig. 3). Similarly, a significant rise was seen in the price index of cereals and vegetable oils for four consecutive months. This was mainly due to the greater shelf life in food commodities (FAO 2020d).

An article revealed that the price of 14 commodities increased by $6.4 \%$ including apples, chicken, potatoes, eggs, beef, milk, rice, tomatoes, cheese, bread, lettuce, onions, and rice based on food price hike in 136 country-food combinations (Nordhagen, 2020). FAO (2020e) highlighted that prices have increased by $20 \%$ in Afghanistan, 35\% in Yemen, and by $50 \%$ in Syria since April and faced severe food shortages in the countries (FAO 2020e). The primary reasons for the price hike during COVID-19 were the demand, panic purchase, and back stocking of goods. Other factors responsible were the shortage of laborers, closure of food processing plants, lack of marketing platform, disruptions in the global supply chain due to travel ban, and sorting of commodities (Sen, 2020). As a long-term effect of the COVID-19 pandemic, this may also lead to inadequacy leading to unemployment, high cost, and low production.

The control of food price hikes is necessary to ensure the accessibility of nutrient-rich diet to the citizens at an affordable right price. Therefore, stringent actions and necessary revisions in the policy frameworks are necessary to control inflation in this sector. As a first step, governments and NGOs should focus on social protection programs for the economically backward classes (M 2019). They should also make sure of the availability of nutrients and food resources for children, women, and other vulnerable communities in specific. Second, timely revision in the trade and tax policies should be done to ensure proper trade and availability of goods inside and outside the country (M 2019). Third, support should be extended to small farms to enhance productivity, pre- and post-harvest loss, and training on opening up e-commerce channels. Finally, initiating food fortification programs in rural areas to provide micronutrients to vulnerable communities is crucial to reduce the effects of the pandemic (Gharibzahedi and Jafari 2017).

\section{Supply chains resilience}

The tremendous amount of disruptions has been caused in the food security and supply chain areas. Leading the supply chain, farmers play a crucial role in land management, crop management, post-harvest, and maintaining soil $\mathrm{pH}$ and moisture. Now, with the advent of the pandemic, workers are finding it a challenge to maintain a balance between labor, social distancing, and livelihood. Restrictions imposed in many parts of the world have made transportation of food and crops close to impossible. A recent report highlighted the shortage of truck drivers for transporting goods in developing countries like India (Saul, 2020a) as workers and migrant laborers in factories or production houses fear to resume work due to the transmission. The lack of raw material supplies to factories has led to the deterioration of quality in the finished product. Ships and huge cargos were forced to lay idle in Asia and Europe following strict quarantine guidelines leading to a huge delay in purchase orders (Todd R Smith 2020). This has led to immense pressure building up indirectly on the consumers as the goods fail to reach the market on time. When it comes to retailers in the USA, the country has faced a $\$ 700$ million hit due to coronavirus. Shipping consultancy Alphaliner estimated the cancellation of $46 \%$ of the scheduled departures from Asia to Europe for more than a month (Saul, 2020b). However, due to the strict local lockdown and increased port congestion, carriers were finding it a challenge to transport goods. The sudden drop in the world's economy and lack of supplies due to transportation barriers has led to a huge rise in the cost of all food commodities.

The Chinese government recently launched a "Clean Plate campaign" where families and groups must order one dish less than the number of total number of diners to understand the food shortage issues and crisis (BBC 2020). When it comes to consumers, the mentality of buying has completely changed in the last few months. The idea of "prioritizing" their list of items has emerged due to the scare of the virus along with job stress. Table 1 gives a detailed description of the immediate, short-term, and long-term impacts on supply chain drivers and food security due to COVID-19 (Mutikani, 2020).

The potential long-lasting impact of COVID-19 is seen on both the demand and supply chain of the food and agricultural sector across the globe. The FAO has highlighted a set of recommendations to tackle the issues related to supply chains: (1) expanding food assistance programs and social protection programs; (2) use of e-commerce channels for purchase and delivery of goods; (3) focus on bottlenecks in logistics department to keep up the food value chain; (4) strategies to keep international trade open and amendment in trade and tax policies; (5) proper management of macroeconomic ramifications (Paulo and Santos Gomes, 2020; Cullen, 2020). In addition to these strategies, good government policies and frameworks are required to minimize the time delay through transportation restrictions. Moreover, the public should encourage the adaptation of local food supply chains to ensure adequate availability of staple foods (Hobbs, 2020). Figure 3 shows the possible implementation of the lean PDCA (Plan-Do-CheckAct) model by the government.

\section{Food security}

Food security means ensuring the availability and accessibility of a sufficient amount of nutrient-rich foods to all communities. Figure 4 explains the range from food security to food insecurity as per USDA (USDA 2019). The main 
Table 1 Impacts on major supply chain drivers due to COVID-19

\begin{tabular}{|c|c|c|c|}
\hline Supply chain drivers & Immediate impacts & Short-term impacts on food security & Long-term impacts on food security \\
\hline Farmers & $\begin{array}{l}\text { - Labor shortage } \\
\text { - Increase in food wastage }\end{array}$ & $\begin{array}{l}\text { - Low profits } \\
\text { - Problems concerned with post- } \\
\text { harvest management }\end{array}$ & $\begin{array}{l}\text { - Loss of income for households } \\
\text { - Issues related to food availability for } \\
\text { lower income community }\end{array}$ \\
\hline Production & Low agricultural yield & $\begin{array}{l}\text { Non-availability of food grains and } \\
\text { staple foods to communities world- } \\
\text { wide }\end{array}$ & Malnutrition, hunger \\
\hline Transportation & $\begin{array}{l}\text { Travel restriction (road, air, and } \\
\text { railways) }\end{array}$ & $\begin{array}{l}\text { Inadequate availability of farm inputs } \\
\text { Increase in supply demand of food due } \\
\text { to closure of restaurants and shop- } \\
\text { ping malls }\end{array}$ & $\begin{array}{l}\text { Food accessibility issues for consumers } \\
\text { Disruption in global trade markets }\end{array}$ \\
\hline Retailers and vendors & Stoppage of imported foods & $\begin{array}{l}\text { Less amount of supply due to lack of } \\
\text { transport and pay cuts }\end{array}$ & $\begin{array}{l}\text { Different cost allocation for PPE (per- } \\
\text { sonal protective equipment) kits to all } \\
\text { workers }\end{array}$ \\
\hline Consumers & $\begin{array}{l}\text { Decreased food supplies } \\
\text { Increased online shopping and scams }\end{array}$ & $\begin{array}{l}\text { Prioritizing on purchase } \\
\text { Work-from-home stress and pressure- } \\
\text { related issues }\end{array}$ & $\begin{array}{l}\text { Lack of food for below-poverty line } \\
\text { globally }\end{array}$ \\
\hline
\end{tabular}

goal of introducing food security is to ensure enhancements in food access. Developing a metric scale for food security could be one of the potential ways to enable adequate food from households to low-income line. Over the last decade, climate change, population boom, hike in food price, and environmental constraints posed a great impact on food security. The international travel restrictions created severe troubles in the production, supply, and trade of agronomical products in the global market (Swinnen and McDermott
2020). In addition to this, many countries imposed stringent social protection measures to combat COVID-19 (Swinnen and McDermott 2020).

Different articles have highlighted the economic fallout across deprived countries in the world. In this global scenario, reports estimated that 140 million people may fall into extreme poverty with a marginal increment of $20 \%$ from the present stages. Food security particularly affected developing countries due to (1) loss of jobs and shortage of income

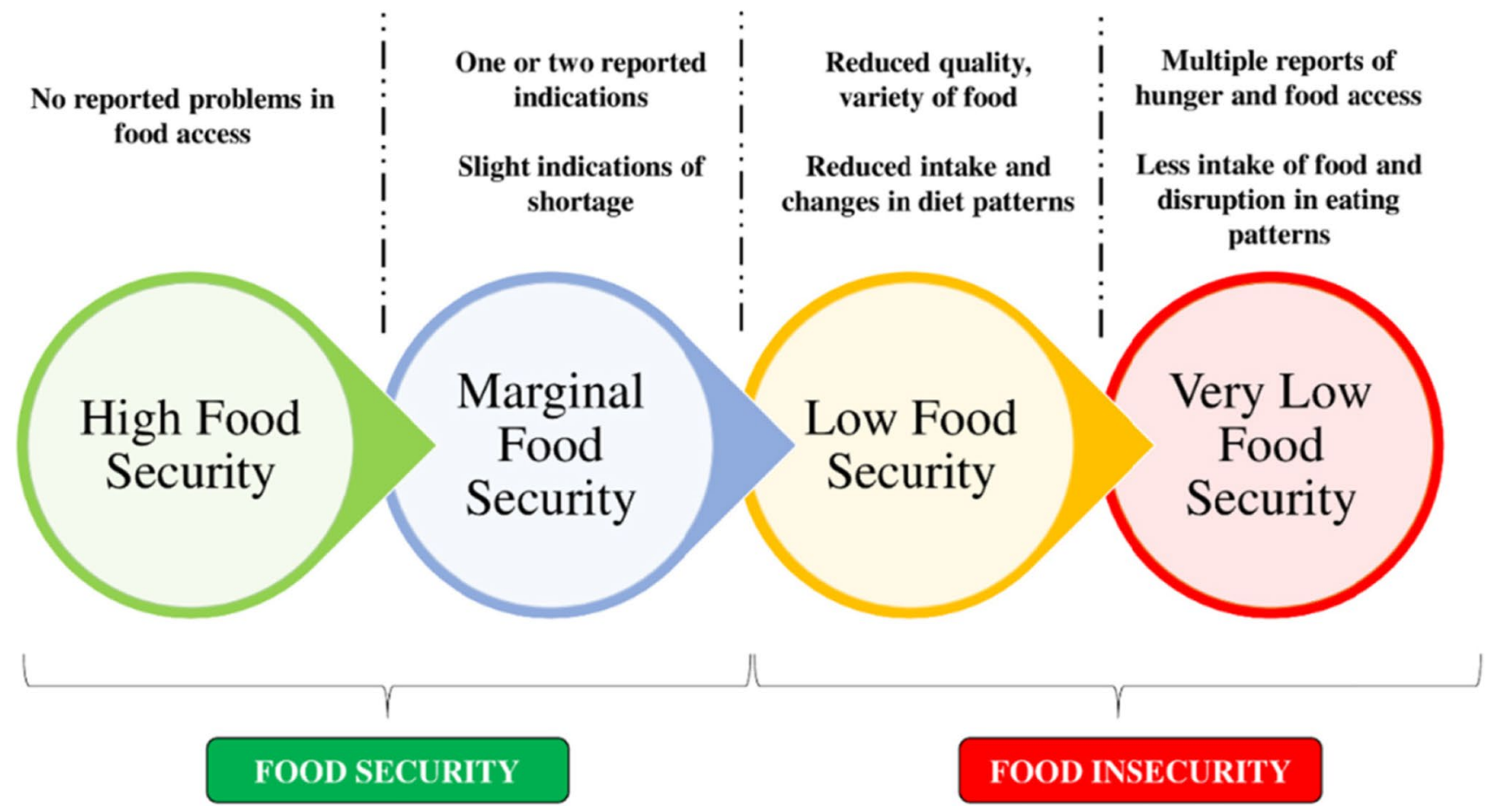

Fig. 4 Ranges of food security as per USDA Economic Research Service (USDA 2019) 
leading to changed consumer behavior; (2) excessive wastage of vegetables, fruits, and dairy products due to inefficient production systems; and (3) disruption of markets and improper public distribution system due to non-availability of food stocks (Bahadur Poudel et al. 2020). The reduction in food production, rapidly declining reserves, and trade constraints are likely to influence food security between 2020 and 2021. The potential impact of COVID-19 on food security can be further prolonged in the form of economic disruptions, lowered investments in the agriculture sector, government expenditure, and financial assistance toward the farmers (Udmale et al. 2020).

Recommendations to ensure food security among the vulnerable community of a society (Lawson-Lartego and Cohen, 2020; FAO 2020e) are as follows: (1) protection of food supply chains and all allied services to ensure the movement of goods, (2) proper utilization of food reserves to meet the requirements according to demands, (3) protection of farmers and food workers by providing subsidized inputs and other services to avoid disruptions in the foodsupply chain; (4) keeping global trade market open to ensure availability of all commodities and avoid price hike due to panic buying or hoarding; (5) adopting sustainable farming practice to meet the daily household demands; (6) introducing social protection programs to reduce the risk of hunger and starvation among vulnerable groups through providing food materials.

\section{Methods to develop a resilient food system}

\section{Adaptation of more resilient food production system based on sustainable forms of agriculture}

FAO explained sustainable agricultural development as a tool for the management and conservation of the natural resource and the orientation of technological change to ensure the satisfaction of human needs for a better tomorrow (FAO 2014) The development of this particular agenda was to achieve zero hunger challenge, environmental advancement, and to attain social sustainability through the development of living standards. Five major principles that balance all the domains like socioeconomic-environmental areas of this sector are listed below (FAO 2014):

- Principle 1: Improving efficiency of food production through proper utilization of resources is important in sustainable agriculture.

- Principle 2: Protection of natural resources.

- Principle 3: If agriculture fails to protect and improve rural livelihoods, equity and social well-being are unsustainable.
- Principle 4: Enhanced resilience of community, citizens, and ecosystem are responsible for sustainability.

- Principle 5: The need for effective governance and supervision.

Sustainable agricultural development can be adopted using different methods either through complete organic agriculture or using different principles. Some of the major sustainable farming methods are reported in Fig. 5. Adopting these agricultural practices improves agriculture production along with the conservation of biodiversity with minimal ecological hazards. Sustainable agriculture methods like urban agriculture and family farming can be practiced in developing a self-sustained agro-food economy to ensure food security.

\section{Urban agriculture}

Urban agriculture is the production of necessary crops and livestock within cities for the benefit of citizens (Zezza and Tasciotti 2010). Innovative and sustainable growing methods used in urban areas are community gardens, rooftop farms, backyard farms and gardens, greenhouse farms, and indoor hydroponic farms. It is also reported that urban farming improved sustainability through integration with building and household wastes (Weidner et al. 2019). Different products like vegetables, cereals, fruits, spices, flowers, dairy, meats, and livestock are produced using urban agriculture (De Bon et al. 2010; Weidner et al. 2019). Urban agriculture

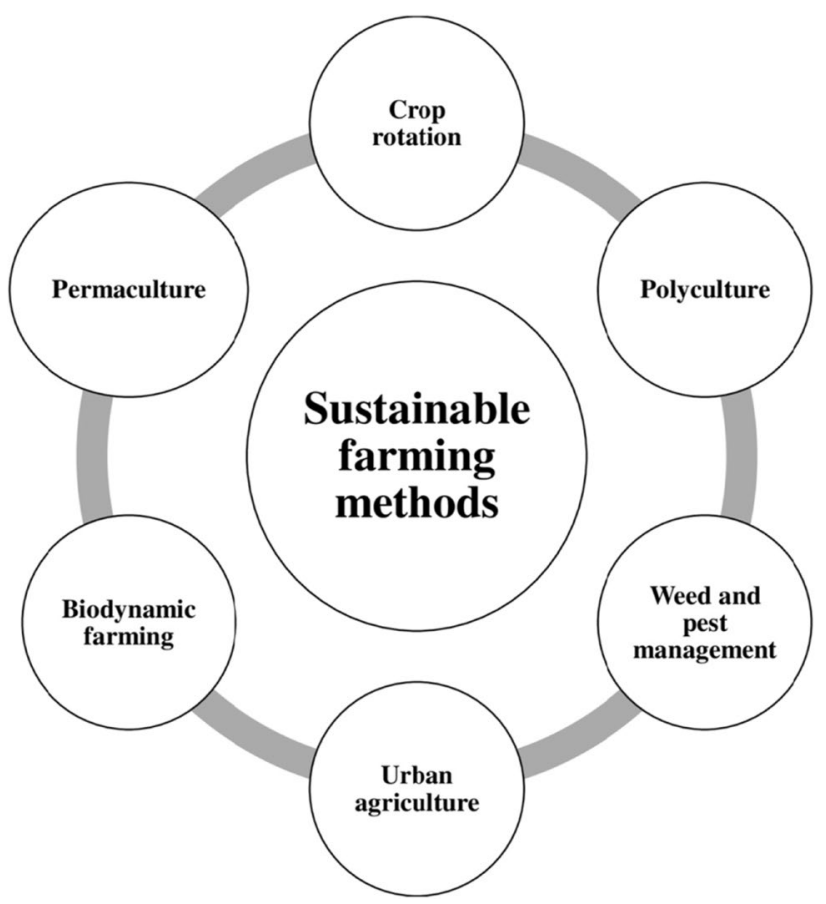

Fig. 5 Sustainable farming methods 
has also shown to generate opportunities in terms of employment and business. A literature study reported the development of urban agriculture in sustainable cities with emphasis on social safety, employment, and promoting environmental sustainability (Azunre et al. 2019).

Urban agriculture can be considered a highly resilient farming technology as it overcomes the short supply chain and diversified farming methods (Khan et al., 2020). The different studies reported that urban agriculture has grown as a sustainable method to ensure food security on the planet. For example, in Cuba, $1 \mathrm{~m}^{2}$ is capable of producing $20 \mathrm{~kg}$ of food items per year. This could meet the daily needs of a family and excess crops can generate income and employment (Altieri and Nicholls (2020). Yoshida and Yagi (2021) emphasized the resilience and sustainability of urban agriculture in Japan. The results indicated that urban farming was resilient to the pandemic and the authors termed this resilience as persistence. Second, sustainable farm activities improved the intentions for the development of farms. The direct marketing strategy, entrepreneurship, and social networks also help urban agriculture. The improved productivity of urban agriculture is the best method to attain local food security by increasing the accessibility of the families toward food. So, urban agriculture can be utilized for post-COVID or any other pandemic which may occur in this world.

\section{Polyculture and crop rotation}

Polyculture is defined as the cultivation of more than one species at the same time and place along with the conservation of biodiversity. Different methods of polyculture include intercropping, cover cropping, strip cropping, and integrated aquaculture (Andow 1991; Bracken 2008). The crop diversity in polyculture helps in the control of pests, weeds, and diseases, with the minimum usage of chemical aids (Iverson et al. 2014). High diversity makes the system more stable toward weather conditions, soil fertility, and maintaining a balanced diet. Therefore, the main advantages of this farming technique are better yield and fast sowing, stable and consistent income, and minimum emission of greenhouse gases. The slower harvest and more economic investment majorly hinder its development on a larger scale. Crop rotation is a sustainable farming method of growing different varieties of crops in a common area across different seasons (Zhao et al. 2020). Crops like legumes (alfalfa, clover), grasses, cereals, and vegetable crops are implemented through intercropping or multiple cropping and an organic approach (Baldwin 2006; Sharma et al. 2018; Zhao et al. 20202020). This strategy will minimize the loss of fertility in the soil where both polyculture and crop rotation use a minimum quantity of chemical fertilizers and pesticides and improve soil fertility. However, special care should be taken in terms of crop selection for a better yield.

\section{Hydroponics}

Hydroponics, in simple terms, refers to a "garden in the absence of soil." This technology aims to grow healthy plants rich in quality and sensory attributes but with the help of light, nutrient dosing, and mineral-rich water. It is reported that by providing the right amount of nutrients and water, the plants grow $50 \%$ faster than they do in soil-based media (Sanchari Pal 2016). Currently, the USA has the fastest moving hydroponics market in the world followed by Europe and Scandinavia. Various agro-food start-ups in the USA promote hydroponics in small-scale farms. In Jordan, FAO launched a project on hydroponic technology on account of water scarcity in the country. The initiative has also aimed to contribute to employment for youth and woman job seekers promoting more opportunities (FAO 2020f). Spain, France, and Netherlands use either large greenhouse agricultural areas or tunnel-like greenhouses to lead a sustainable environment. Scandinavian countries have increased their demand for this technology due to harsh climatic conditions. The plants are grown indoors in many households during winters (ValueStrat 2019). Figure 6 shows the working methodology of a hydroponic system. India and China too are improving and investing heavily in this technology due to their large population density and lack of available land. Advantages are efficient water use, limited pesticides, and higher yields and food production throughout the year. So, hydroponics is a well-known planting methodology for the cultivation of crops in the urban areas where fertile land is highly limited (Khan et al., 2020).

\section{Family and community farming}

Family farming and community farming are vital to the economies of all countries. The objective of these techniques is to produce and deliver food that is environmentally, economically, and nutritionally sustainable. Family farming is developing family farms through their labor, land, dedication, and passion on a small scale for their needs. It is an opportunity to develop family-based agriculture in the world for food security, socio-ecological sustainability, and economic development (Graeub et al. 2016). Latin American countries like Brazil, Uruguay, and Paraguay have taken positive steps to combat the world food crisis by encouraging local family farming (Cervantes-Zapana et al. 2020).

Similarly, the community-supported agriculture or community farm is a direct partnership between farmers and a consumer group to share the risk and responsibilities of farming operations. Community farming follows the agroecological method to produce high-quality food materials. 


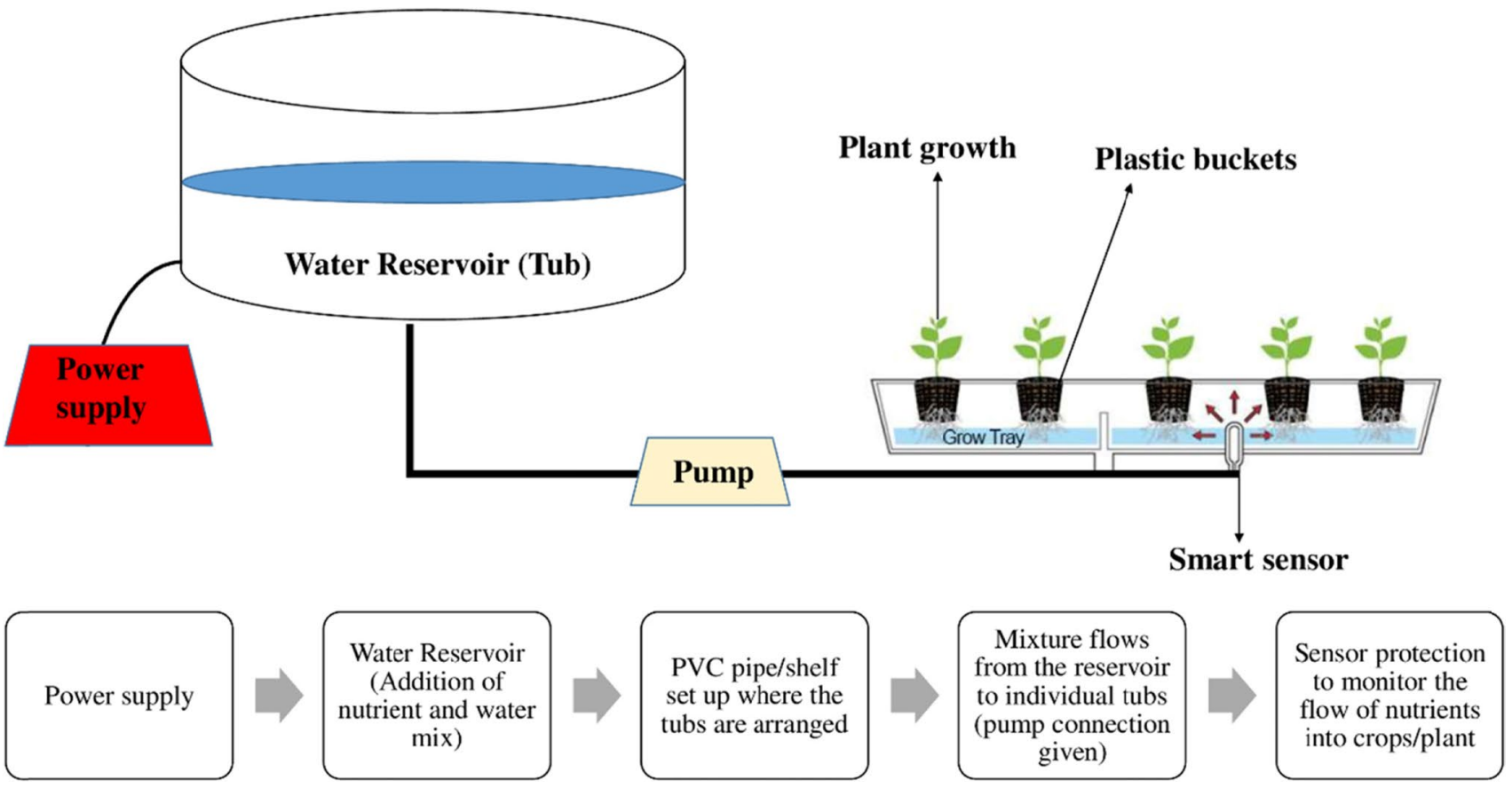

Fig. 6 Work flow schematic of a hydroponic system

This method also develops an alternative distribution system through direct contact with the farmers that is independent of traditional market behavior. This results in sales of farm products locally which benefits both consumers and farmers.

Group farming on the family basis or community base is always better than individual farming as they can enjoy the economies of scale, higher investible funds, skills, and minimized input costs. One such example is the group farming stated by the Government of Kerala through the women group farm under the Kudumbashree mission. Currently, there are almost 68,000 farms across the state, which are maintained by women. Studies claimed that the group farms of Kerala yielded 1.8 times the annual value of output per hectare and fivefold net return. The study also proved that the group farms survived the pandemic as they were able to sell their products locally and through the community kitchens under the tag of Kudumbashree (Shagun, 2021). Haga (2020) described that adopting such farming methods is beneficial to meet the demands of the domestic markets. The involvement in the market at the local level is helpful to ensure the continuous food supply which is helpful to overcome the issues created by COVID-19 regarding logistical and transport issues. The use of family members as labor avoids the labor shortage. Resilient farmers are necessary to develop a resilient food system. Small farming can build a resilient food system in a post-COVID world.

The concept of family farming and community farming is dependent on the policy of individual countries that describe the production of goods relied on labor and land. Along with the maintenance of rural sustainability and economy, they always tend to enhance natural resources. The advantages of these farming methods are economic benefits, better productivity, food security, social inclusion, employment, crop diversification, and minimum $\mathrm{CO}_{2}$ emission (Cervantes-Zapana et al. 2020). The adoption of these farming practices will ensure the adequate availability of food resources and maintain food security in this scenario. Recommendations to strengthen family and community farming activities (Bruil, 2014) are as follows:

- Adopting cross-sectoral and territorial approaches to integrate rural development (rural infrastructure, traditions, indigenous knowledge, culture, youth development).

- The strengthening of technical capabilities of rural communities through rapid training and education programs.

- Developing stronger farmer organization to consolidate the voice of farmers in policymaking and framework of new regulations.

- Accessibility of natural resources like water, land, and adopting voluntary guidelines.

- Improving trade and building markets for promotion of local markets, storage, and transportation. 


\section{Advantages, challenges, and recommendations}

Through adopting these techniques, we can improve the agriculture distribution that may be helpful to yield integration of natural biological cycles and controls. This development tool (1) protects and enriches the fertility of the soil and natural resource base, (2) minimizes the production inputs, (3) reduces the usage of renewable resources, (4) conserves energy with minimum emission of greenhouse gases, (5) improves food production with minimal waste, and (6) promotes family farming and family communities. During this scenario, the development of a sustainable agriculture system will always help people to be self-dependent as they will cultivate crops for their family more organically and sustainably. Along with these advantages, sustainable agriculture development creates job opportunities through which food security can ensure and further benefited in poverty alleviation. Therefore, the practice of sustainable agriculture development is a key strategy to be addressed as it makes self-sufficient economies during pandemics like COVID-19.

The major challenges in adopting sustainable agriculture developments are discussed below:

1. Availability of water: To address sustainable agriculture, the proper use and conservation of water is extremely important. The present farming systems face extreme stress in the availability of water due to water pollution and drought along with inefficient irrigation practices. As a result, farmers of Egypt have shifted to cultivation of commercial crops like wheat and cotton which utilize minimum quantity of water (Shalaby et al. 2011). Therefore, significant importance should be given to irrigation management to address the issues related to water utilization. Recommendations to improve water utilization are as follows:

2. Rainwater harvesting involves collection of rainwater mainly from rooftops and swollen streams. This technique ensures that farmers have a substantial amount of water stored during the summer season.

3. Adopt lining channels or closed conduits to reduce conveyance loss.

4. Avoid over-irrigation to restrict surface water runoff and percolation loss.

5. Use of drip-irrigation systems or a sprinkler system to minimize transportation loss during irrigation.

6. Availability of land resources: The need for fertile land is a driving force for the cultivation of any type of crop. The deterioration of land quality is due to seasonal shifts, surface erosions, and waterlogging. Along with urbanization and industrialization, climate change is also attributed to land loss in different regions like Africa, South America, India, and Europe (Zhang and Cai 2011). Therefore, the practice of sustainable methods like hydroponics, polyculture, urban farming, and family farming is encouraged due to minimal land requirements. The efficient land utilization can be achieved using the following:

7. The need for proper land reclamation policies.

8. Adopting hydroponics and vertical farming for the cultivation of vegetables and to overcome issues related to land availability.

9. Encourage organic farming to maintain soil fertility.

10. Soil testing at regular intervals to assess the $\mathrm{pH}$ and other soil parameters.

11. Lack of support services towards farmers: Farmers find inadequate support services with respect to accessibility of farm inputs like seeds, fertilizers, etc. Most of the rural farmers face inadequate access toward extension services and technology transfer. The farmers belonging to rural side of India and African countries lack knowledge in advanced technologies related to crop protection and management (Shalaby et al., 2011). However, an efficient and extensive support center can be developed through introducing $24 * 7$ call centers and special training programs on advanced technologies.

Other recommendations also include the following:

- Fixed cash transfers and an improved supply chain. With the ill-effects of the pandemic rising exponentially, setting targets play a crucial role for effective planning.

- Coping strategies like setting up a specific amount or a donation limit which needs to be provided to lowerincome class, migrants, laborers, and pregnant women at such uncertain times (Workie et al., 2020). Such strategies will improve the livelihoods of the country as well as control the economy of the country.

- Global food decentralization: increasing the usage of local food products and processing technologies most suited for the particular environmental condition. The system makes an attempt to improve the countries' economic growth, thereby saving logistics time making it more self-reliant. For instance, countries like Uganda made an attempt to build a decentralization system from district to village level (Nathan et al., 2020). Continuous campaigns were undergone to strengthen this system, making it better for households to receive food at the right time. The method has also noticed resilience in countries like the UK having a remarkable adaptive capacity (Dominic et al., (2020). It is noteworthy to mention that the whole process involves least involvement with stakeholders and third parties, thereby reducing costs with an improved planning.

- Adopting digital technologies for crop monitoring and pest management, developing advanced eco-agricultural 
engineering models based on the suitability of applications, implementing an awareness program on the usage of pesticide and its health hazards, development of proper food storage and processing industries, and good government policy and framework to support farmers.

\section{Technology-supported agricultural development}

Innovative opportunities toward technology advancements are one of the most promising approaches toward improving consumer demands across the world. Adequate focus should be given to business models and salient features as mentioned in the UN 2030 Sustainable development agenda (Nilsson et al. 2016). It is important to understand the changing needs of consumers with time to remove the inefficiencies in the agricultural system. One possible path to handle post-pandemic situations is adopting advanced technologies in the agrofood sector. The key aspects for future enhancements should be addressed mainly on three factors: economic, environmental, and social impact of the product/process. The following are the technological and financial developments that can be introduced for progressing toward improving the sustainability and the production component in the system.

\section{Digitalization}

The digitalization of agriculture is one of the areas widely given importance in recent years as it could be the next agricultural revolution. Figure 7 gives a detailed understanding of the versatility of digitalization post-pandemic in different sectors with a major focus on agro-food sector. Table 2 shows the utilization of digital technologies from producers to consumers. The technology could help farmers understand their land and crop better by offering information and collecting data on crops, weather forecasts, soil conditions, crop quality, and fertilizer management. In addition, farms will also be able to reduce costs by applying the concept of digital tools through the usage of robotics and autonomous machines (Mentsiev et al. 2020). When it comes to food processing units, usage of sensors and sensor-based technologies could enhance the overall productivity of food commodities. For instance, an investigation on application of sensor-based chips was analyzed as they had the potential to inhibit oxygen and maintain food quality (Gaikwad et al. 2018). In recent years, machines have also been equipped with sensors to detect foreign particles or waste in food (Islam et al. 2020). Thus, we can conclude that the utilization of creative and innovative technologies could have a huge potential in changing the methodology of production, delivery, and consumption of foods.

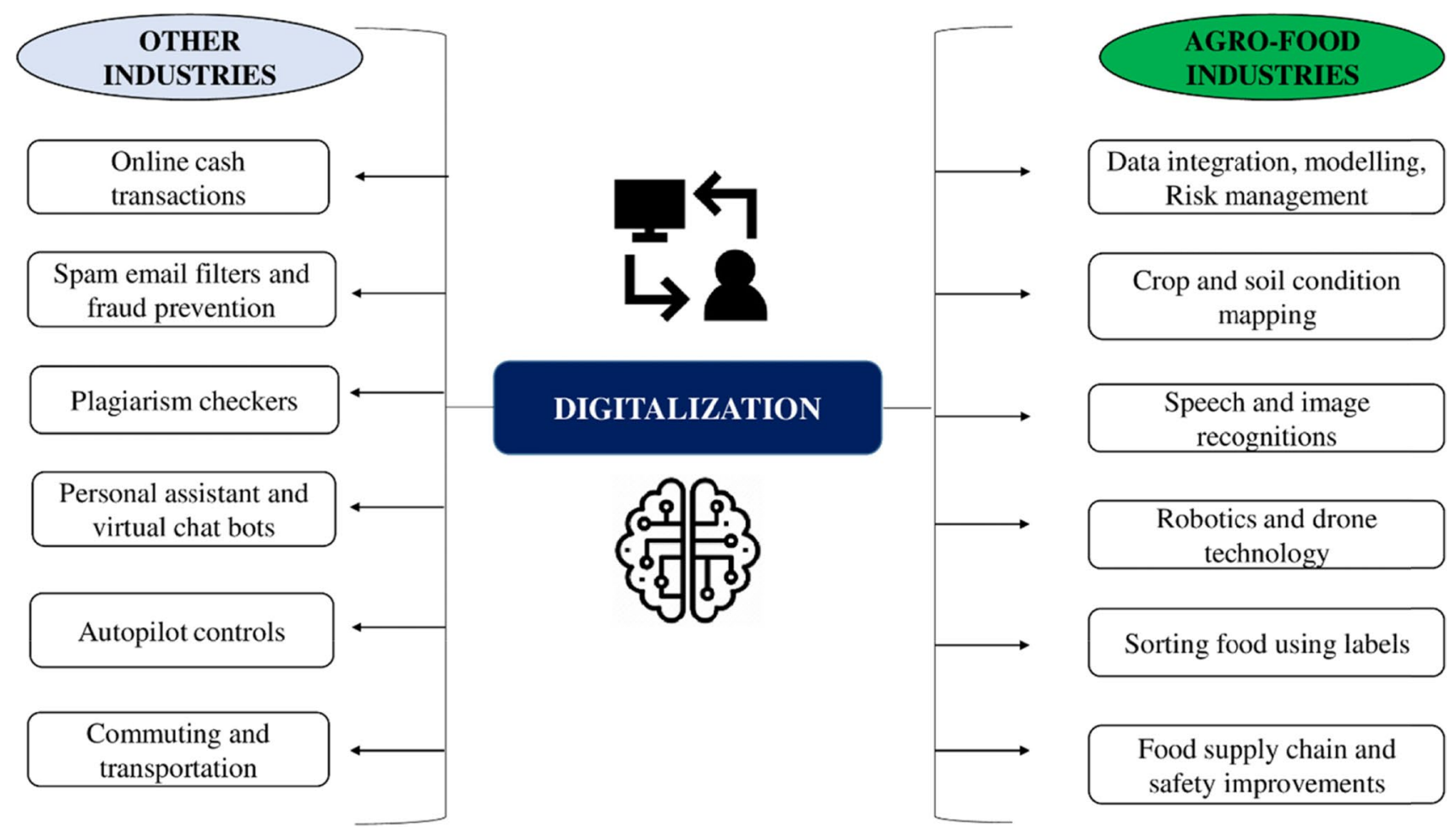

Fig. 7 Versatility of digitalization post-pandemic in various sectors with a major focus on agro-food sector 
Table 2 Utilization of digital technologies from producer to consumer

\begin{tabular}{|c|c|c|c|}
\hline Category & Criteria & Key insights & Usage of digital tools \\
\hline \multirow[t]{5}{*}{ Consumer } & Farm to fork process & $\begin{array}{l}\text { Need for locally fresh foods in the shortest } \\
\text { time possible }\end{array}$ & Block-chain systems, mobile apps \\
\hline & Payment process & $\begin{array}{l}\text { Receiving offers, discounts from time to } \\
\text { time } \\
\text { Avoiding cash transaction (due to contact) } \\
\text { Payment security system }\end{array}$ & Digital wallets, zero-contact payment \\
\hline & Comfort and convenience & $\begin{array}{l}\text { Wide product range } \\
\text { Saving time to go to local store } \\
\text { Ordering at your convenience } \\
\text { Recommending others to buy the product } \\
\text { based on experience }\end{array}$ & Social media platforms, websites \\
\hline & Trust and reliability & Doorstep delivery reliability & GPS-based tracking systems \\
\hline & Food safety and nutrition & $\begin{array}{l}\text { Eco-friendly product } \\
\text { No artificial additives } \\
\text { Good product quality }\end{array}$ & Carbon footprint software \\
\hline \multirow[t]{4}{*}{ Producer } & Resource management and product quality & Human labor, machines, robots & Robotics and drones \\
\hline & Inbound and outbound logistics & $\begin{array}{l}\text { Supply of raw materials } \\
\text { Process monitoring, improving innovations }\end{array}$ & Internet of Things, AI, ML, deep learning \\
\hline & Sustainability & $\begin{array}{l}\text { Capacity increase with good sustainable } \\
\text { practices at all channels }\end{array}$ & Deep learning \\
\hline & Legal and standards & Complying to the food standards at all times & Digital certificates \\
\hline
\end{tabular}

The integration of information technology (IT) with agriculture and food production has shown remarkable progress in improving productivity and aiding farming to make informed decisions. A good example of this is the introduction to precision agriculture. This farming involves an innovative concept, which uses the principles of AI to process data for a value-added agriculture. The technology could help farmers understand their land and crop better by offering information and collecting data on crops, weather forecasts, soil conditions, crop quality, and fertilizer management. In addition, farms will also be able to reduce costs by applying the concept of digital tools through the usage of robotics and autonomous machines (Mentsiev et al. 2020).

The concept of AI involves subfields mainly ML, deep learning, and neural networks. Figure 8 involves the application of subfields of AI. In recent years, machine learning and deep learning has gained a lot of interest in the agro-food sector. ML works under running algorithms for statistical predictions and inferences (Smith et al 2019). For instance, a study proposed an ML-based integrated approach to forecast the seasonal rainfall for assessing the climatic conditions in Australia (Feng et al. 2020). Gümüşçü et al. 2019 estimated the wheat crop planting date using ML algorithms based on the available climatic data. The data was collected and processed using genetic algorithms, where farmers could analyze the conditions and take decisions. A study was also conducted on mapping the carrot yield based on concepts of precision agriculture and ML (Wei et al. 2020). Recently, a biosensor chip was introduced in China which uses the concept of AI and ML to keep track of pigs' age, location, and health in farms (Houser, 2018). A US-based agri-food company introduced agri-robots and self-driving tractors which helped farmers pick and pack strawberries and pepper (CROO 2014; Faggella 2020). An agri-tech start-up in Berlin, Germany, developed an application that can monitor soil crops just by clicking photos. The software reads the photo and understands soil defects, detect pests in land, and show the crop efficiency patterns using principles of ML and IoT (Kennepoh, 2020). This posed an essential tool for making decisions on improving agricultural practices.

Another innovative field growing under the concept of $\mathrm{AI}$ is deep learning. The concept focuses on the processing of appropriate datasets to get the desired output (Chen and Ran 2019). Deep learning has proven effective in handling many vision-based tasks like image recognition, classification, segmentation, object analysis, and fruit detections. This can be seen clearly with the analysis done by Balasubramanian et al. who studied plant phenotyping for efficient crop management using deep learning theories (Balasubramanian et al. 2020). Advancements in deep learning theories with machine learning have led to predictions of large amounts of data, automatic extraction, and better efficiency in agricultural methodologies. Usage of sensors and sensor-based technologies could enhance the overall productivity of food commodities. For instance, Gaikwad et al. (2018) investigated the application of sensor-based chip in packaging which can inhibit the oxygen and determine the food quality. The chip, once installed, can detect the quality of the food 


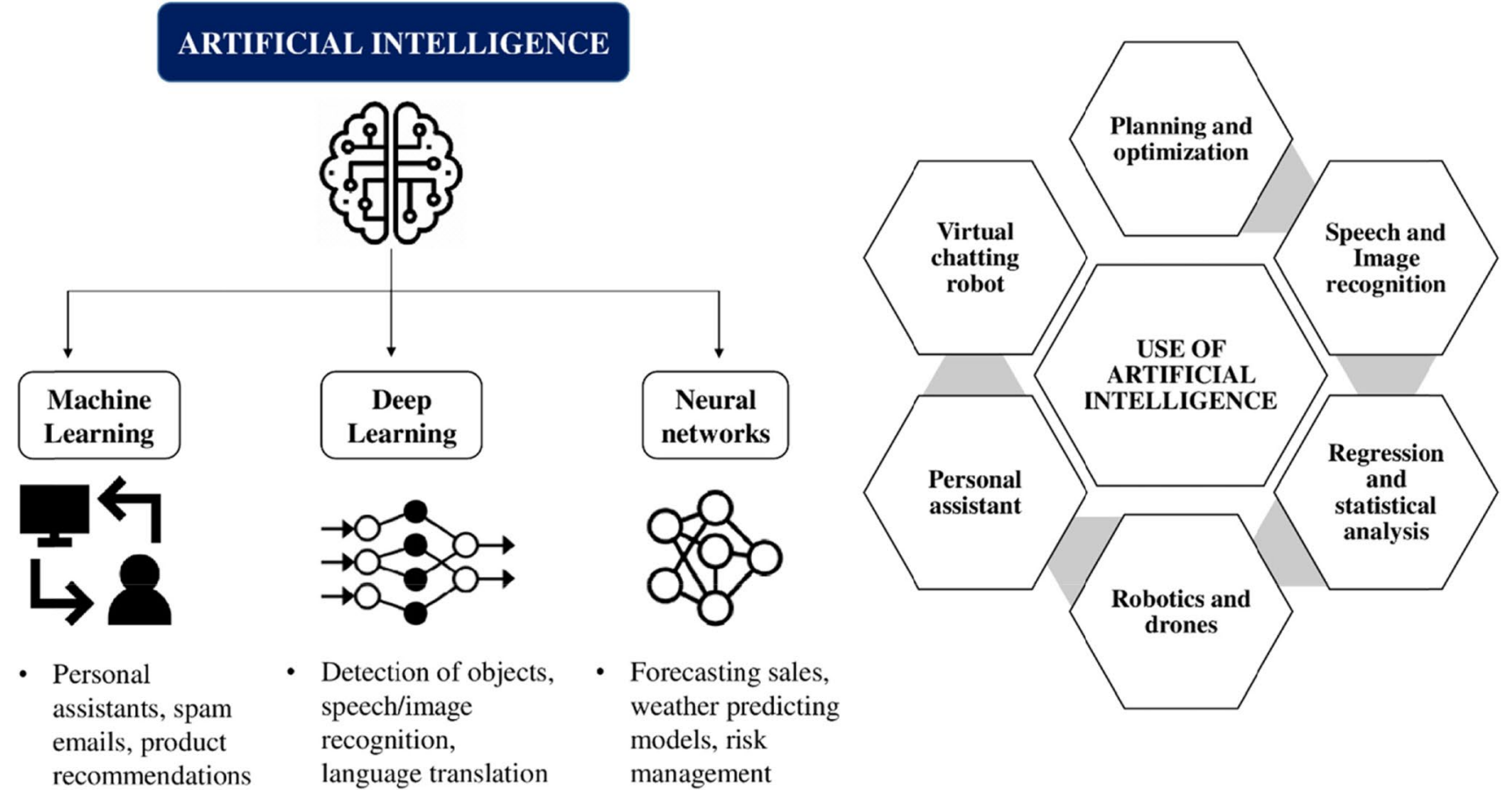

Fig. 8 Application of subfields of AI in agro-food sector

product within seconds. In recent years, machines have also been equipped with sensors to detect foreign particles or waste in the food production line (Islam et al., 2020). They serve as a dual purpose in helping the whole supply chain in analyzing crop conditions and detecting weeds or pests in large farms thus balancing the overall yield. Although these technologies are in their nascent stages, there is a huge potential to diversify with a faster speed to market.

Overall, the utilization of these technologies is highly beneficial for attaining a resilient agricultural system. Digital tools such as artificial intelligence help the farmers to be preemptive regarding the pest treatment that can curb crop damage and save money. The key advantages are as follows: (1) they help farmers know the information about soil, crop yields and weather patterns through IoT sensors and satellites; (2) application of innovation agriculture increases yields and profits; (3) the digital agriculture is transforming the food production and helps us to grow using minimum resources and investment. Thus, we can conclude that the utilization of creative and innovative technologies could have a huge potential in changing the methodology of production, delivery, and consumption of foods.

\section{Block-chain technology}

Addressing food and supply-chain distribution, emerging digital strategies like block-chain technology will allow easier trade and transactions. Block-chain will allow greater transparency in the supply chain and agriculture, thus reducing unwanted and untrusted parties. The agro-food system network utilizing block-chain can be described in the following process:

1. Farmer: Receives information about crops, fertilizer dosage and requirements, pesticides, and tools needed using web services, agricultural scientists, and food technologists. Transactions between the distributor and farmer are recorded.

2. Production line: Food production methodology, processing, fertilizer dosage, nutrient control, and soil management data are stored using sensors and drones.

3. Retailer: Logistics, export, shipping, and time details are recorded and monitored. Financial transactions done are recorded in the block-chain network, thus notifying the suppliers.

4. Consumer: Food commodity is shipped to the supermarket where barcode scanning processes the information and connects the sales success to the whole supply chain.

Block-chain will allow greater transparency in the supply chain and agriculture, thus reducing unwanted and untrusted parties (Kamilaris et al. 2019). A recent article by the World Economic Forum published in The Economic Times proposed a "block chain deployment toolkit" with an aim to maximize the benefits with the least risks providing a lean 
technology. The kit will cover aspects and best practices executed across industries, multinationals, startups, academic institutions, and supply-chain departments to ensure cooperation and accelerate the economy in post-pandemic state (World Economic Forum 2020). Currently, North America owns the largest share of the world's block-chain technology in food supply chains and agricultural markets. This could be majorly due to food safety concerns leading to greater research and development. Europe, on the other hand, is looking for opportunities in agriculture and supplychain markets with block-chain technology (Market growth 2018). When it comes to Switzerland, it was highlighted that the country has a separate section on "economy" in its constitution keeping agriculture on par with other sectors like banking, beverage, and gaming (Goedde et al. 2017). In Asia, China and India have the fastest growing market and excellent forecast accuracy due to the increasing food wastage population.

The block-chain technologies are deployed to yield high efficiency and the integrity of the agricultural applications. As a summary, the main uses of the block-chain are (1) provenance traceability and food authentication, (2) smart farming data management, and (3) supply-chain management. The implementation of block-chain can be concluded as an efficient and promising technology for the rise in agriculture and improvement in food supply chain distribution.

\section{Conclusion}

The unprecedented pandemic has posed several challenges in the agro-food systems worldwide affecting major areas of production, dietary changes, environment, transportation, and overall supply chain. Restrictions in movements, variations in supplies, and challenges in logistics due to social distancing and strict quarantine measures have posed huge barriers in providing affordable and nutritious food to all. Therefore, food systems and food security are significantly interrupted with a higher impact on the vulnerable population. Thus, one of the key lessons learned due to the spread of the virus would be building a resilient food system. The growth of advanced technologies in the industry as discussed in this review may play a key role in enhancing food-supply practices. Innovations like developing new products, services, and introducing new financial schemes which address challenges faced in agricultural sectors would be the key to achieve sustainability. Family farming and community farming make our households and individuals more selfsustainable. The drastic changes in human behaviorism with respect to the eating and purchasing habits tending to a more nutritious and plant-based food may grow in the future. The advent of digitalization and the growth of digital marketing would allow customers to order and deliver any item at their doorstep. Thus, we can conclude that understanding the gravity of the situation and acting effectively will aid a more socio-technologically innovative ecosystem.

Author contribution AS: investigation, writing the original draft preparation. $\mathrm{AB}$ : writing the original draft preparation, review and editing, formal analysis and investigation. MMJ: review and editing, formal analysis and investigation. MS: review and editing. ND: supervision, review and editing, formal analysis.

Funding The authors did not receive support from any organization for the submitted work.

\section{Declarations}

Consent to participate All authors have consented to brainstorm and to participate in the research study.

Consent for publication All of the authors have given their consent to publish this manuscript.

Competing interests The authors declare no competing interests.

\section{References}

Abbott S, Hellewell J, Munday J, Funk S (2020) The transmissibility of novel Coronavirus in the early stages of the 2019-20 outbreak in Wuhan: exploring initial point-source exposure sizes and durations using scenario analysis. Wellcome Open Res. https://doi. org/10.12688/wellcomeopenres.15718.1

Adebayo B. Aromolaran and Milu Muyanga (2020) Impact of COVID19 on agriculture, food systems and rural livelihoods in Nigeria. https://doi.org/10.19088/APRA.2020.005

Affognon H, Diallo Y, Bohissou F, Jalloh A. et al (2020) Adapting agricultural production to COVID-19 in West Africa? http:// www.coraf.org/?sBlog\%3AAdapting_AgriculturalProduction_ to_COVID19_in_West_Africa

Afzal I, Kamran M, Ahmed Basra SM et al (2020) Harvesting and post-harvest management approaches for preserving cottonseed quality. Ind Crops Prod 155:112842. https://doi.org/10.1016/j. indcrop. 2020.112842

Alexander Kennepoh (2020) Plantix. In: PEAT. https://www.crunc hbase.com/organization/peat

Allen RC (2000) Economic structure and agricultural productivity in Europe, 1300-1800. Eur Rev Econ Hist 4:1-25. https://doi.org/ $10.1017 / \mathrm{s} 1361491600000125$

Altstedter A (2020) Is India fast becoming the world's new coronavirus epicentre? https://www.bloom/bergquint.com/coronavirus-outbr eak/india-becoming-virus-hotspot-to-watch-with-cases-to-topbrazil. Accessed on 31 August 2020

Altieri MA, Nicholls CI (2020) Agroecology and the reconstruction of a post-COVID-19 agriculture. J Peasant Stud 47(5):881-898. https://doi.org/10.1080/03066150.2020.1782891

Andow DA (1991) Vegetational diversity and arthropod population response. Annu Rev Entomol. https://doi.org/10.1146/annurev. en.36.010191.003021

Arora NK, Mishra J (2016) Prospecting the roles of metabolites and additives in future bioformulations for sustainable agriculture. Appl Soil Ecol 107:405-407. https://doi.org/10.1016/j.apsoil. 2016.05.020 
Azunre GA, Amponsah O, Peprah C et al (2019) A review of the role of urban agriculture in the sustainable city discourse. Cities. https:// doi.org/10.1016/j.cities.2019.04.006

Balasubramanian VN, Guo W, Chandra AL, Desai SV (2020) Computer vision with deep learning for plant phenotyping in agriculture: a survey. Adv Comput Commun 1-26. https://doi.org/10. 34048/acc.2020.1.f1

Baldwin KR (2006) Crop rotations on organic farms. In: Crop rotations versus continuous cropping - North Carolina Coop Ext Serv. Baldwin KR, Rotations C, Page F (2006). https://www. carolinafarmstewards.org/wp-content/uploads/2012/12/7-CEFSCrop-Rotation-on-Organic-Farms.pdf

Baloch MA, Thapa GB (2019) Review of the agricultural extension modes and services with the focus to Balochistan, Pakistan. J Saudi Soc Agric Sci 18:188-194. https://doi.org/10.1016/j.jssas. 2017.05.001

Baoua IB, Amadou L, Baributsa D, Murdock LL (2014) Triple bag hermetic technology for post-harvest preservation of bambara groundnut (Vigna subterranea (L.) Verdc.). J Stored Prod Res 58:48-52. https://doi.org/10.1016/j.jspr.2014.01.005

BBC (2020) China launches "Clean Plate" campaign against food waste. BBC. https://www.bbc.com/news/world-asia-china-53761 295. Accessed August 2020

Bracken MES (2008) Monocultures versus polycultures. In: Encyclopedia of Ecology. https://doi.org/10.1016/B978-008045405-4. 00521-8

Bruil J (2014) Towards stronger family farms: recommendations from the International Year of Family Farming. ILEIA, Center for learning on sustainable agriculture. http://www.agriculturesnet work.org/magazines/global/reclaiming-nutrition/recommenda tions-from-iyff

Cervantes-Zapana M, Yagüe JL, De Nicolás VL, Ramirez A (2020) Benefits of public procurement from family farming in LatinAmerican countries: identification and prioritization. J Clean Prod 277:123466. https://doi.org/10.1016/j.jclepro.2020. 123466

Chatterjee R (2020) Indian agriculture and role of agricultural extension system to cope up with COVID-19 crisis. 1:10-15. https:// foodandscientificreports.com/assets/uploads/issues/1587983397 indian_agriculture_and_role_of_agricultural_extension_system. pdf

Chen J, Ran X (2019) Deep learning with edge computing: a review. Proc IEEE 107. https://doi.org/10.1109/JPROC.2019.2921977

Christiaensen L, Martin W (2018) Agriculture, structural transformation and poverty reduction: eight new insights. World Dev 109:413-416. https://doi.org/10.1016/j.worlddev.2018. 05.027

Consultancy.asia (2020) Covid-19's impact on India's agricultural sector. https://www.consultancy.asia/news/3364/covid-19s-impacton-indias-agricultural-sector. Accessed July 2020

CROO (2014) Harvest CROO Robots. http://harvestcroo.com/about/

Cullen MT (2020) COVID-19 and risk to food supply chains: how to respond? http://www.fao.org/2019-ncov/analysis/en/. Accessed March 2020

Daum T, Birner R (2020) Agricultural mechanization in Africa: myths, realities and an emerging research agenda. Glob Food Sec 26:100393. https://doi.org/10.1016/j.gfs.2020.100393

De Bon H, Parrot L, Moustier P (2010) Sustainable urban agriculture in developing countries. A review. Agron. Sustain. Dev. https:// doi.org/10.1051/agro:2008062

De Janvry A, Sadoulet E (2020) Using agriculture for development: supply- and demand-side approaches. World Dev 133:105003. https://doi.org/10.1016/j.worlddev.2020.105003

De Paulo FD, dos Santos Gomes MG (2020) COVID-19 outbreak: what should be done to avoid food shortages? Trends Food Sci Technol 102:291-292. https://doi.org/10.1016/j.tifs.2020.06.007
Dominic M, Frances C, Magnus M, Peter A (2020) UK food system resilience tested by COVID-19. Nature Food. https://doi.org/10. 1038/s43016-020-0082-1)

Eisenberg J (2020) How scientists quantify the intensity of an outbreak like COVID-19. In: Michigan Heal. Lab Rounds. https://labblog. uofmhealth.org/rounds/how-scientists-quantify-intensity-of-anoutbreak-like-covid-19 Accessed 17 March 2020

Faggella D (2020) AI in agriculture - present applications and impact. In: EMERJ

Food and Agriculture Organization of United Nations FAO (2020a) Migrant workers and the COVID-19 pandemic. Migr Work COVID-19 pandemic 4-8. http://www.fao.org/3/ca8559en/ CA8559EN.pdf Accessed 7 April 2020a

Food and Agriculture Organization of United Nations FAO (2020b) Mitigating risks to food systems during COVID-19: reducing food loss and waste http://www.fao.org/3/ca9056en/CA9056EN. pdf . Accessed 11 May 2020b

Food and Agriculture Organization of United Nations FAO, 2020c. Impact of the Covid-19 pandemic on food security and food systems. FAO Council. 12 CL 164/10, 6-10 July 2020c. http:// www.fao.org/3/nd059en/ND059EN.pdf . Accessed 13 July 2020c

Food and Agriculture Organization of United Nations FAO (2020d) FAO food price index. http://www.fao.org/worldfoodsituation/ foodpricesindex/en/. Accessed September 2020d

Food and Agriculture Organization of United Nations FAO (2020e) Q\&A: COVID-19 pandemic-impact on food and agriculture. http://www.fao.org/2019-ncov/q-and-a/impact-on-food-and-agric ulture/en/

Food and Agriculture Organization of United Nations FAO (2020f) Home Gardens/Vertical Farming, Hydroponics and Aquaponics. http://www.fao.org/land-water/overview/covid19/homegardens/ en/

Food and Agriculture Organization of United Nations FAO (2014) Building a common vision for sustainable food and agriculture: principles and approaches

Feng P, Wang B, Liu DL, et al (2020) Machine learning-based integration of large-scale climate drivers can improve the forecast of seasonal rainfall probability in Australia. Environ Res Lett 15. https://doi.org/10.1088/1748-9326/ab9e98

Gaikwad KK, Singh S, Lee YS (2018) Oxygen scavenging films in food packaging. Environ Chem Lett 16:523-538. https://doi.org/10. 1007/s10311-018-0705-z

Gharibzahedi SMT, Jafari SM (2017) The importance of minerals in human nutrition: bioavailability, food fortification, processing effects and nanoencapsulation. Trends Food Sci Technol 62:119132. https://doi.org/10.1016/j.tifs.2017.02.017

Goedde L, Denis N, Tanaka M, et al (2017) Building a food security strategy for Japan in an age of global competition. https://www. mckinsey.com/ /media/mckinsey/featured\%20insights/asia\% 20pacific/food $\% 20$ security\%20in\%20japan\%20building\%20a\% 20strategy\%20in\%20an\%20age\%20of\%20global\%20competit ion/building-a-food-security-strategy-for-japan-in-an-age-ofglobal-competition-english.pdf. Accessed December 2017

Graeub BE, Chappell MJ, Wittman $\mathrm{H}$ et al (2016) The state of family farms in the world. World Dev 87:1-15. https://doi.org/10.1016/j. worlddev.2015.05.012

Gregorio G, Ancog R (2020) Assessing the impact of the COVID-19 pandemic on agricultural production in Southeast Asia: toward transformative change in agricultural food systems. Asian J Agric Dev 17:3-51. https://doi.org/10.37801/ajad2020.17.1.1

Gümüşçü A, Tenekeci ME, Bilgili AV (2019) Estimation of wheat planting date using machine learning algorithms based on available climate data. Sustain Comput Informatics Syst. https://doi. org/10.1016/j.suscom.2019.01.010

Haga M, (2020) Small-scale farmers can help build resilient food systems in a post-COVID-19 world. https://www.ifad.org/en/web/ 
latest/-/blog/small-scale-farmers-can-help-build-resilient-foodsystems-in-a-post-covid-19-world

Hellin J, Balié J, Fisher E et al (2020) Sustainable agriculture for health and prosperity: stakeholders' roles, legitimacy and modus operandi. Dev Pract. https://doi.org/10.1080/09614524.2020. 1798357

Hobbs JE (2020) Food supply chains during the COVID-19 pandemic. Can J Agric Econ 68:171-176. https://doi.org/10.1111/cjag. 12237

Houser K (2018) Chinese farmers are using AI to track and monitor pigs. Futurism. https://futurism.com/at-tracks-pigs-chine se-farmers

Insights W (2020) Impact of COVID-19 on smallholder farmers insights from India. https://www.wbcsd.org/Overview/NewsInsights/WBCSD-insights/Impact-of-COVID-19-on-small holder-farmers-in-India. Accessed June 2020

Islam T, Yousuf M, Nauman M (2020) A highly precise cross-capacitive sensor for metal debris detection in insulating oil. Rev Sci Instrum 91. https://doi.org/10.1063/1.5139925

Iverson AL, Marín LE, Ennis KK, et al (2014) Do polycultures promote win-wins or trade-offs in agricultural ecosystem services? A meta-analysis. J. Appl. Ecol. https://doi.org/10.1111/13652664.12334

Jámbor A, Czine P, Balogh P (2020) The impact of the coronavirus on agriculture: first evidence based on global newspapers. Sustain 12:1-10. https://doi.org/10.3390/su12114535

Kamilaris A, Fonts A, Prenafeta-Boldó FX (2019) The rise of blockchain technology in agriculture and food supply chains. Trends Food Sci Technol 91:640-652. https://doi.org/10.1016/j.tifs. 2019.07.034

Khan MM, Akram MT, Janke R, Qadri RWK, Al-sadi AM, Farooque AA (2020) Urban horticulture for food secure cities through and beyond COVID-19. Sustainability 12(22):9592. https://doi. org/10.3390/su 12229592

Kumar V, Singh SB, Singh S (2020) COVID-19: environment concern and impact of Indian medicinal system. J Environ Chem Eng 8:104144. https://doi.org/10.1016/j.jece.2020.104144

Laborde D, Martin W, Swinnen J, Vos R (2020) COVID-19 risks to global food security. Science 369:500-502. https://doi.org/10. 1126/science.abc4765

Lawson-Lartego L, Cohen MJ (2020) 10 recommendations for African governments to ensure food security for poor and vulnerable populations during COVID-19. Food Secur 12:899-902. https://doi.org/10.1007/s12571-020-01062-7

Luckstead J, Nayga RM, Snell HA (2020) Labor issues in the food supply chain amid the COVID-19 pandemic. Appl Econ Perspect Policy 00:1-19. https://doi.org/10.1002/aepp.13090

M. PK (2019) Review: Global food insecurity set to rise because of COVID-19. In: https://factly.in/review-global-food-insecurityset-to-rise-because-of-covid-19/

Mandal P, Gupta AK, Dubey BK (2020) A review on presence, survival, disinfection/removal methods of coronavirus in wastewater and progress of wastewater-based epidemiology. J Environ Chem Eng 106192. https://doi.org/10.1016/j.eplepsyres.2019. 106192

Market growth (2018) Blockchain in Agriculture Market (and Food Supply Chain), Application (Product Traceability, Payment and Settlement, Smart Contracts, and Governance, Risk and Compliance Management), Provider, Organization Size, and Region - Global Forecast to 2023. Mark. Mark

Mengoub FE (2020) Policy brief. Ensuring food security during the Covid-19 pandemic: review of short term responses in selected countries. https://www.policycenter.ma/sites/default/ files. Accessed April 2020

Mentsiev AU, Amirova EF, Afanasev N V. (2020) Digitalization and mechanization in agriculture industry. IOP Conf Ser Earth
Environ Sci 548. https://doi.org/10.1088/1755-1315/548/3/ 032031

Mutikani L (2020) Coronavirus deals U.S. economy Great Depressionlike job losses, high unemployment. Reuters. https://www.reute rs.com/article/us-usa-economy-idUSKBN22K1NS. Accessed May 2020

Nathan I et al (2020) COVID-19 relief food distribution: impact and lessons for Uganda. Pan Afr Med Journal. 35(2):142. https://doi. org/10.11604/pamj.supp.2020.35.142.24214

Ng'ang'a J, Mutungi C, Imathiu S, Affognon H, (2016) Effect of triple-layer hermetic bagging on mould infection and aflatoxin contamination of maize during multi-month on-farm storage in Kenya. J Stored Prod Res 69:119-128. https://doi.org/10.1016/j. jspr.2016.07.005

Nilsson M, Griggs D, Visbeck M (2016) Policy: Map the interactions between Sustainable Development Goals. Nature 534:320-322. https://doi.org/10.1038/534320a

Nordhagen S (2020) covid-19-and-food-prices-what-do-we-knowso-far.pdf. https://www.gainhealth.org/media/news/covid-19and-food-prices-what-do-we-know-so-far. Accessed May 2020

OECD (2020) Food supply chains and COVID-19: impacts and policy lessons. Comp. Cris. Gt. Lockdown versus Gt. Recess. http://www.oecd.org/coronavirus/policy-responses/food-supply-chains-and-covid-19-impacts-and-policy-lessons-71b57 aea/. Accessed on 2 June 2020.

Poudel K, Subedi P (2020) Impact of COVID-19 pandemic on socioeconomic and mental health aspects in Nepal. Int. J. Soc. Psychiatry. https://doi.org/10.1177/0020764020942247

Poudel PB, Poudel MR, Gautam A, et al (2020) COVID-19 and its global impact on food and agriculture. J Biol Today's World 9:221. https://doi.org/10.35248/2322-3308.20.09.221

Pu M, Zhong Y (2020) Rising concerns over agricultural production as COVID-19 spreads: lessons from China. Glob. Food Sec. https://doi.org/10.1016/j.gfs.2020.100409

Qiao H, Zheng F, Jiang H, Dong K (2019) The greenhouse effect of the agriculture-economic growth-renewable energy nexus: evidence from G20 countries. Sci Total Environ 671:722-731. https://doi.org/10.1016/j.scitotenv.2019.03.336

Rajput H, Changotra R, Rajput P et al (2020) A shock like no other: coronavirus rattles commodity markets. Environ Dev Sustain. https://doi.org/10.1007/s10668-020-00934-4

S. Mahendra Dev (2020) Addressing COVID-19 impacts on agriculture, food security, and livelihoods in India. IFPRI Blog. https://fpri.org/blog/addressing-covid-19-impacts-agriculturefood-security-and-livelihoods-india. Accessed April 2020

Saadat S, Rawtani D, Hussain CM (2020) Environmental perspective of COVID-19. Sci Total Environ 728:138870. https://doi.org/ 10.1016/j.scitotenv.2020.138870

Sanchari Pal (2016) Growing soil-less with hydroponics: an introduction to innovative farming at home. The Better India. https://www.thebetterindia.com/60350/soil-less-hydroponicgardening-india/. Accessed July 2020

Saul J (2020a) Shipping lines, ports count cost as coronavirus hits supply chains. Reuters. https://www.reuters.com/article/uschina-health-shipping-idUSKBN20E2GN. Accessed February 2020

Saul J (2020b) U.S. retailers face $\$ 700$ million hit as virus disrupts ocean shipping. Reuters. https://finance.yahoo.com/news/uretailers-face-700-mln-204607163.html. Accessed March 2020

Sen S (20AD) COVID-19 Lockdown: Barring Cereals, Prices Of Key Staples Surged Three Times In A Month. Log. Indian. https:// thelogicalindian.com/news/food-prices-surge-3-times-20549. Accessed June 2020

Shagun (2021) Group farming can transform agriculture post-COVID-19. https://www. downtoearth.org.in/inter views/agriculture/group-farming-can-transform-agric 
ulture-post-covid-19-77346. https://www.downtoearth.org.in/ interviews/agriculture/group-farming-can-transform-agriculturepost-covid-19-77346. Accessed June 2021

Shalaby MY, Al-Zahrani KH, Baig MB et al (2011) Threats and challenges to sustainable agriculture and rural development in Egypt: implications for agricultural extension. J Anim Plant Sci 21:581-588

Sharma A, Padhee AK, Kumar S (2020a) How Indian agriculture should change after COVID-19. Food Sec 12(2020):837-840. https://doi.org/10.1007/s12571-020-01063-6

Sharma HB, Vanapalli KR, Cheela VS et al (2020b) Challenges, opportunities, and innovations for effective solid waste management during and post COVID-19 pandemic. Resour Conserv Recycl 162:105052. https://doi.org/10.1016/j.resconrec. 2020.105052

Sharma P, Singh A, Kahlon CS et al (2018) The role of cover crops towards sustainable soil health and agriculture-a review paper. Am J Plant Sci. https://doi.org/10.4236/ajps.2018.99140

Sharma R, Shishodia A, Kamble S et al (2020c) Agriculture supply chain risks and COVID-19: mitigation strategies and implications for the practitioners. Int J Logist Res Appl 1:27. https://doi. org/10.1080/13675567.2020.1830049

Smith et al (2019) Getting value from artificial intelligence in agriculture. Anim Prod Sci 60:46-54. https://doi.org/10.1071/AN18522

Swinnen J, McDermott J (2020) COVID-19 and global food security. https://doi.org/10.2499/p15738coll2.133762

Task A (2019) Israeli precision agriculture start-up Agri task secures $\$ 8.5 \mathrm{M}$ in ag-insurance oriented financing ground. Tel Aviv. https://www.potatopro.com/news/2019/israeli-precision-agric ulture-startup-agritask-secures-85m-ag-insurance-oriented. Accessed November 2019

Todd R Smith (2020) Global trade challenges: penetrating the supply chain black hole $\&$ assessing incentives. Reuters https://blogs. thomsonreuters.com/answerson/global-trade-challenges-toddsmith/. Accessed April 2020

Torero, M., 2020b. Prepare food systems for a long-haul fight against COVID-19. 2 July 2020. IFPRI Blog. https://www.ifpri.org/ blog/prepare-food-systems-long-haul-fight-against-covid-19. Accessed 7 July 2020

Udmale P, Pal I, Szabo S et al (2020) Global food security in the context of COVID-19: a scenario-based exploratory analysis. Prog Disaster Sci 7:100120. https://doi.org/10.1016/j.pdisas.2020. 100120

USDA (2019) Definitions of Food Security. https://www.ers.usda.gov/ topics/food-nutrition-assistance/food-security-in-the-us/measu rement.aspx. Accessed September 2021

Usman M, Farooq M, Hanna K (2020) Environmental side effects of the injudicious use of antimicrobials in the era of COVID-19. Sci Total Environ 745:141053. https://doi.org/10.1016/j.scito tenv.2020.141053

ValueStrat (2019) Hydroponics: is it a worthwhile investment for the Middle East's food and agriculture sector? https:// medium.com/@valustrat/hydroponics-is-it-a-worthwhile-inves tment-for-the-middle-easts-food-and-agriculture-sector-b2117 e714fd2. Accessed May 2018

Wei MCF, Maldaner LF, Ottoni PMN, Molin JP (2020) Carrot yield mapping: a precision agriculture approach based on machine learning. Ai 1:229-241. https://doi.org/10.3390/ai1020015

Weidner T, Yang A, Hamm MW (2019) Consolidating the current knowledge on urban agriculture in productive urban food systems: learnings, gaps and outlook. J Clean Prod. https://doi.org/ 10.1016/j.jclepro.2018.11.004

WFO (2020a) Covid-19 pandemic outbreak: overview of the impact on the agricultural sector. https://www.wfo-oma.org/wp-content/ uploads/2020a/05/COVID19-WFO-technicalassessment_00508 2020a.pdf. Accessed May 2020

WFO (2020b) COVID-19 Agri-Information Hub 1-9. https://www. wfo-oma.org/covid-19-agri-information-hub/. Accessed October 2020

World Health Organization WHO (2020) Coronavirus mortality rate. In: World of Meters. Accessed August 2020

WFP, 2020b. World Food Programme to assist largest number of hungry people ever, as coronavirus devastates poor nations. https:// www.wfp.org/news/world-food-programme-assist-largest-number-hungry-people-ever-coronavirus-devastates-poor Accessed 7 July 2020

Workie E, Mackolil J, Nyika J, Ramadas S (2020) Deciphering the impact of COVID-19 pandemic on food security, agriculture, and livelihoods: a review of the evidence from developing countries. Curr Res Environ Sustain 100014. https://doi.org/10.1016/j. crsust.2020.100014

World Economic Forum (2020) Blockchain technology can tackle supply chain failures exposed by COVID-19, boost economic recovery: WEF. The Economics Times. https://economictimes.india times.com/tech/internet/blockchain-technology-can-tackle-supply-chain-failures-exposed-by-covid-19-boost-economic-recov ery-wef/articleshow/75430872.cms. Accessed Apr 2020

Yoshida S, Yagi H (2021) Long-term development of urban agriculture: resilience and sustainability of farmers facing the Covid-19 pandemic in Japan. Sustainability 13(8):416. https://doi.org/10. 3390/su 13084316

Zezza A, Tasciotti L (2010) Urban agriculture, poverty, and food security: empirical evidence from a sample of developing countries. Food Policy. https://doi.org/10.1016/j.foodpol.2010.04.007

Zhang X, Cai X (2011) Climate change impacts on global agricultural land availability. Environ Res Lett 6. https://doi.org/10.1088/ 1748-9326/6/1/014014

Zhao J, Yang Y, Zhang K, et al (2020) Does crop rotation yield more in China? A meta-analysis. F. Crop. Res. https://doi.org/10.1016/j. fcr.2019.107659

Publisher's Note Springer Nature remains neutral with regard to jurisdictional claims in published maps and institutional affiliations. 